\title{
The Positive Impact of Teams Games Tournament Learning Model Assisted with Video Media on Students' Mathematics Learning Outcomes
}

\author{
Ida Ayu Kadek Sri Puspita Dewi \\ Program Studi Pendidikan Guru Guru Sekolah Dasar, FIP, Universitas Pendidikan Ganesha, Singaraja, Indonesia \\ Email:nimadeevadiantari@gamil.com
}

Kadek Suranata

Program Studi Bimbingan Konseling, FIP, Univeristas Pendidikan Ganesha, Singaraja, Indonesia Email: kadek.suranata@undiksha.ac.id

Ni Wayan Arini

Program Studi Pendidikan Guru Guru Sekolah Dasar, FIP, Universitas Pendidikan Ganesha, Singaraja, Indonesia Email: wayanarini@yahoo.co.id

\section{A R T I C L E I N F O \\ Article history: \\ Article history: \\ 1 Mei 2020 Received in \\ revised form \\ 11 Juni 2020 \\ Accepted 10 Juli 2020 \\ Available online 25 Agustus 2020}

\section{Kata Kunci:}

teams games tournament,

video, matematika

Keywords:

teams games tournament, video, mathematic Matematika siswa kelas V.

\begin{abstract}
A B S T R A K
Rendahnya hasil belajar Matematika siswa kelas V menjadi permasalahan utama penelitian ini. Hal ini disebabkan karena guru belum menerapkan model pembelajaran yang dapat mengaktifkan siswa dalam pembelajaran, kurangnya penggunaan media dalam proses pembelajaran yang diberikan guru, siswa jarang belajar Matematika, dan kurang berkonsentrasi pada saat menerima pelajaran Matematika. Penelitian ini bertujuan untuk menganalisis pengaruh model pembelajaran Teams Games Tournament (TGT) berbantuan media video terhadap hasil belajar Matematika siswa kelas V. Jenis penelitian ini adalah eksperimen semu dengan desain non-equivalent post-test only control group. Populasi penelitian ini berjumlah 137 orang siswa. Pengambilan sampel menggunakan teknik intact group, sehingga diperoleh sampel penelitian yaitu siswa kelas V yang berjumlah 52 orang siswa. Data hasil belajar Matematika siswa dikumpulkan menggunakan metode tes yaitu dengan tes objektif dalam bentuk pilihan ganda yang berjumlah 24 soal. Hipotesis penelitian diuji dengan menggunakan uji-t. Berdasarkan hasil analisis data, diperoleh $t_{\text {hitung }}=14,354>\mathrm{t}_{\text {tabel }}=2,021$ (pada taraf signifikansi 5\%). Hasil uji hipotesis menunjukkan bahwa terdapat perbedaan yang signifikan hasil belajar Matematika siswa. Dengan demikian, dapat disimpulkan bahwa es Tournament (TGT) berbantuan media video berpengaruh terhadap hasil belajar
\end{abstract}

\begin{abstract}
A B S T R A C T
The low of Mathematics learning outcomes of the fifth-grade students are the main problem in this study. It is because the teacher has not implemented a learning model that can enable students in the learning process, the lack of use of media in the learning process provided by the teacher, students study Mathematics rarely, and the lack of concentration in receiving Mathematics. This study aimed to determine the effect of the video media assisted Teams Games Tournament (TGT) learning model on the Mathematics learning outcomes of the fifth-grade students. This research was a quasi-experimental with using non-equivalent post-test only control group design. The population of this research was 137 students. This study applied an intact group technique so the research sample of fifth grade students was 52 students. The students' Mathematics learning outcomes were collected by using an objective test method through 24 multiple choice questions. The research hypothesis was tested using t-test. Based on the results of data analysis, the researcher obtained $t_{\text {count }}=14,354>t_{\text {table }}=2,021$ (at a significance level 5\%). The result of hypothesis test indicated that there was a significant difference on students' Mathematics learning outcomes. Thus, it can be concluded that the video media assisted Teams Games Tournament (TGT) significantly influences the mathematics learning outcomes.
\end{abstract}

\section{Introduction}

Mathematics is one of the most difficult subjects compared to other subjects, especially for students at the primary education level. The basis for learning Mathematics is to instill the basic concepts of simple mathematics which become students' initial knowledge (Mariani, 2017; Cahyaningsih, 2017). Mathematics can contribute to solve daily problems. Therefore, students need to master mathematics well (Wajo \& Kartika 2020; Rahmawati, 2017). Mathematics learning emphasizes the learning process that can provide good understanding, 
persistence, intelligence, and behavior changes that can be applied in student's daily life. Many attempts have been made to make mathematics become an enjoyable subject. Various learning methods and approaches have been developed to make students enjoy mathematics. Thus, Mathematics learning that is taught in the classroom should be interesting, easy for students to understand, inspiring, challenging, actively involved, and ultimately making students smart in learning Mathematics (Mariani, 2017; Novianingsih, 2016; Syarir \& Kusnadin, 2013). To achieve the objectives of the Mathematics subject, the teacher must strive all students to understand the material.

However, in a reality, Mathematics is considered as difficult subject by some students. This is supported by (Solihah's study, 2016) which states that students complain about the many formulas and rules that must be memorized and understood in their use. Students generally only memorize Math formulas to solve problems. Students become lazy to learn or practice or feel unhappy with Mathematics which decreases Mathematics learning outcomes (Damayanti, 2017; Pangestu \& Santi, 2016). Learning outcomes can be interpreted as the level of student success in learning subject matter at school which is expressed in obtained scores from the results of certain subject tests. Mathematics learning outcomes are abilities achieved by students after participating in Mathematics learning activities that can be measured using evaluation tools Nawawi in (Susanto, 2013; Bungsu et al., 2019; Egok, 2017). The process of learning mathematics in schools is generally classical, namely the teacher provides an explanation of the material being taught to students. Communication that occurs in a learning system like this tends to be one-way which causes students to only accept the knowledge given and they become passive in the learning process.

This problem also occurred in Elementary School in Cluster VI, Seririt District. Based on the results of interviews with the fifth grade teacher of elementary school in Cluster VI, Seririt District that was conducted on November $4^{\text {th }}$ and $5^{\text {th }}, 2019$, obtained information, namely: 1) the teacher had not used a learning model that could activate students in learning; 2) the lack of media implementation given by teacher in learning; 3 ) students rarely learn Mathematics and do not concentrate in learning Mathematics so that students' abilities in Mathematics subject matter are low.

Apart from interviews, observations were also made to the class. The results of the observation showed that some students were still doing homework in class and students rarely discussed Mathematics in class. The teacher only applied the lecture method of learning. Teachers rarely form student groups to work together between group members so that students do not participate actively in learning. In addition, students become bored and lack concentration in learning. Students' attention is easily distracted by other things outside of the lesson, such as playing, disturbing their friends, and talking to their friends so that class conditions like this are not optimal for continuing the learning process. After making observations, a documentation study was then conducted.

Documentation studies were conducted to strengthen and clarify the results of interviews and observations that had been conducted. Based on the results of recording documents at Elementary School in Cluster VI, Seririt District, a list of the results of the Mathematics Final Exam was obtained in the cognitive domain of fifth grade students in the first semester in academic year 2019/2020 school year. Based on data collection, the average score of students' mathematics learning outcomes was still below the KKM (minimum completeness criteria). 103 students who did not reach the KKM were more than 34 students. The average percentage of students who reached the KKM was $25.19 \%$ and students who had not reached the KKM were 74.81\%. This shows that the results of Mathematics Middle Test in the cognitive domain of the fifth grade students in Cluster VI, Seririt District are still low.

Inline the problems above, it is necessary to apply an innovative and fun learning model for students so that it can improve students' Mathematics learning outcomes. This is supported by the opinion of (Hermayanti, 2017) which states that students can use innovative and fun learning models to improve student learning outcomes. The Teams Games Tournament learning model is one type of cooperative learning models that is easy to be applied, involves the activities of all students without status difference, involves roles among students, contains elements of play and reinforcement (Hakim, 2017; Komalasari, 2010; Oktarianingsih, 2018).

The distinctive features that distinguish the Teams Games Tournament learning model from other cooperative learning models are the existence of inter-group tournaments and the students are free to actualize themselves (Candra, 2017; Ismah \& Ernawati, 2018). The learning model of Teams Games Tournament or team game matches was originally developed by David De Vries and Keath Edward. The Teams Games Tournament learning model is used to help students with less abilities to understand the material. In this model, students play a game with other team members to get additional points for their team score which can make fun learning for students. The designed games learning activities using the TGT learning model can make students learn more relaxed and more actively collaborate with groups (Candra, 2017; Ismah \& Ernawati, 2018). The TGT learning model can be used in various subjects from elementary school to university (Candra, 2017; Ismah \& Ernawati, 2018). Thus, it can be concluded that the Teams Games Tournament learning model is a type of cooperative 
learning model that contains elements of academic games (tournament) by involving the learning activities of each student member in a heterogeneous group through collaboration to earn points for the team.

There are three basic reasons for choosing the Teams Games Tournament (TGT) type cooperative learning model as an alternative solution to improve student mathematics learning outcomes. First, it is based on the teacher's view that elementary school students really like various forms of games so the Teams Games Tournament learning model can make students happier to join the learning. This opinion is supported by a study conducted by (Bahagiani, 2017) which states that elementary school students really like various forms of games. Second, based on the information given by the fifth grade elementary school teacher in Cluster VI, Seririt District, this model has never been used, especially in teaching students on Mathematics subject matter. Third, students can play an active role in learning, can work together with group members in completing assignments given by the teacher, and study harder to improve students' Mathematics learning outcomes. It is inline with a study conducted by (Saptayanti, 2016) where students study harder after applying the Teams Games Tournament learning model. In addition, (Setiawan, 2017) also supports that students can play an active role in learning without depending on the teacher after implementing the Teams Games Tournament learning model. Students can be responsible, motivate each other and work together in solving problems or tasks from the teacher.

This present study is different from the previous Teams Games Tournament learning model. The difference between previous study and the present study is that the Teams Games Tournament learning model can be assisted by instructional video media. The Teams Games Tournament learning model is assisted by video media to improve student mathematics learning outcomes, which are still low. Instructional video media are media or tools that present audio and visuals containing good learning message such as, concepts, principles, procedures, and knowledge to understand learning material (Dewi, 2019). Thus, it can be concluded that video media is a medium that presents information in the form of sound and visual to direct students' attention in learning through messages and information. The advantages of video media, namely, it can attract attention for short periods, save time, present concrete learning objects or realistic learning messages, and it can be repeated so that the video content is easy to be understood. It can be used for both classical and individual way. Mathematics learning media in the form of video is used in the classroom to make it easier for students to understand a concept. This is supported by (Supryadi, 2013) which states that the advantages of video media can be used as a solution to overcome students' low abilities in understanding a concept. Video in learning related to building space subject matter. The syntax of the Teams Games Tournament (TGT) learning model assisted by video media is the presentation of classes, groups, games, tournaments, and group awards. Through the application of the Teams Games Tournament (TGT) learning model assisted by video media, it allows students to learn in an active and fun atmosphere to improve students' Mathematics learning outcomes.

Based on the description above, the objective of this study was to analyze the effect of the Teams Games Tournament (TGT) learning model assisted by video media on the mathematics learning outcomes in the fifth grade students in Cluster VI, Seririt District, Academic Year 2019/2020. The collaboration between the TGT model and audio visual media will make the learning atmosphere more enjoyable and students will become more motivated in learning so that the results of learning mathematics can increase.

\section{Method}

The present study was experimental research. Experimental research is a research that is intended to determine whether or not there is an effect of a particular treatment on changes in certain conditions or circumstances Masyhud (Maulidina, 2018). In this study, a quasi-experiment was used due to the limitation of researcher. The research design was the Non-equivalent Post-test Only Control Group Design. The purpose of this design was to decide two groups randomly from the existing population. The first group was given a treatment while the second group was not given treatment. The first group was the experimental group while the second group was the control group. At the end of the study, the two groups got the same measurements to obtain data on s' mathematics learning outcomes.

All objects in a study are called as the research population (Agung, 2014). The population of this study was all the fifth grade students in Cluster VI Seririt District, Buleleng Regency in academic year 2019/2020 which consisted of seven schools. The public elementary schools were SD Negeri 1 Patemon, SD Negeri 2 Patemon, SD Negeri 3 Patemon, SD Negeri 4 Patemon, SD Negeri 5 Patemon, SD Negeri 1 Unggahan, and SD Negeri 2 Unggahan. In this study, members of the population were used as the research sample so the intact group technique was applied. The intact group technique is a random sampling technique where all the randomized population is a class. Intact group technique is used because simple random cannot be done (Dantes, 2017). After taking the sample using the intact group technique, a group of 26 students from SD Negeri 4 Patemon was assigned as an experimental group who were treated with the video media assisted Teams Games Tournament (TGT) learning model and a group of 26 students from SD Negeri 1 Unggahan was the control group who were not treated with the video media assisted Teams Games Tournament (TGT) learning model. 
This research procedure consisted of three stages, namely the research preparation stage, the research implementation stage, and the final research stage. In the preparation stage, the activities were 1) visiting elementary schools in Cluster VI, Seririt District and asking permission from the school principal to conduct research; 2) conducting observations and interviews with the principal in Cluster VI Seririt District and the fifth grade teachers in each school where the research was carried out; 3) asking for mid-semester test data of the fifth grade students in Cluster VI, Seririt District; 4) performing the intact group technique to determine the experimental group and the control group; 5) compiling lesson plans and preparing learning resources that were used in carrying out learning activities during the research; 6) compiling research instruments in the form of multiple choice objective tests to measure students' Mathematics learning outcomes; 7) conducting judges or expert validation tests and research instrument trials; 8) consulting the lesson plans that had been made with the supervisor and the fifth grade teacher before conducting the research. At the research implementation stage, the activities were giving treatment to the experimental group in the form the video media assisted Teams Games Tournament (TGT) learning model while there was no treatment given to the control group. Whereas in the final stage of the research, post-test was prepared to the experimental group and the control group to obtain data on students' mathematics learning outcomes.

The needed data in this study was the data on students' mathematics learning outcomes. Data collection activities were conducted in the fifth grade students Cluster VI, Seririt District, academic year 2019/2020. To collect data in this study, the test method was used. This test method was conducted by distributing several tests to measure students' Mathematics learning outcomes in the form of a multiple choice test of 24 questions with four alternative answers (a, b, c, and d). The research instrument was developed based on basic competencies and indicators in learning guided by the 2013 curriculum. The basic competencies were: 3.5 explaining and determining the volume of space using volume units (such as unit cubes) and the relationship of cube with cube roots and 3.6 explaining and find a simple space net (cubes and blocks). The post-test was data collection technique about the mathematics learning outcomes in the fifth grade elementary school Cluster VI Seririt District. The post-test aimed to measure students' abilities. Before the test was given to students, the instrument was tested first, namely testing the validity, reliability, difficulty level, and different power.

After the data in this study were collected, then data analysis was conducted. In this study, descriptive statistical analysis techniques and inferential statistics were used to analyze the data. Descriptive statistical analysis is used to analyze data by describing the collected data. Descriptive statistics included the presentation of data by calculating the mean, median, mode, standard deviation, and variance. Meanwhile, inferential statistical analysis was used to test the research hypothesis using the t-test (Independent Samples Test) assisted by SPSS 17.0 for Windows program at a significance level of 0.05 . Before testing the research hypothesis, prerequisite testing was conducted first, namely the normality test of the data distribution and the homogeneity test of variance.

\section{Result and Discussion}

In this study, the data were mathematics learning outcomes in the cognitive domain obtained from the students' post-test results of SDN 4 Patemon as an experimental class that was taught using video media assisted Teams Games Tournament learning model and SDN 1 Unggahan as the control group who were not given a treatment. The recapitulation of the post-test result data from the experimental group and the control group was presented in Table 1 as follows.

Table 1. The Recapitulation of Post-test Result

\begin{tabular}{ccc}
\hline Analysis Result & Experimental Group & Control Group \\
\hline Mean & 18.85 & 11.77 \\
Median & 19 & 11.50 \\
Mode & 20 & 11 \\
Standard Deviation & 1.54 & 1.88 \\
Variance & 2.37 & 3.53 \\
Maximum Score & 22 & 16 \\
Minimum Score & 16 & 9 \\
\hline
\end{tabular}

Based on the analysis results of the table above, it can be described that the data on the mathematics learning outcomes of the experimental group, namely, mean $=18.85$; median $=19$; mode $=20$; standard deviation $=1.54$; and variance $=2.37$. While the control group mathematics learning outcomes data, namely: mean $=11.77 ;$ median $=11.50 ;$ mode $=11 ;$ standard deviation $=1.88 ;$ and variance $=3.53$. The maximum scores of the experimental group and the control group were 22 and 16, while the minimum scores of the experimental 
group and control group were 16 and 9. This indicates that the mathematics learning outcomes of the experimental group were higher than the control group.

Before testing the research hypothesis using the t-test, prerequisite testing was done including the distribution normality test and the variance homogeneity test. The data distribution normality test for Mathematics learning outcomes scores was conducted using the Kolmogorov-Smirnov and Shapiro-Wilk techniques using SPSS 17.0 for Windows at the 0.05 significance level. The test criteria using the SPSS 17.0 for Windows program in the Kolmogorov-Smirnov and Shapiro-Wilk tests were normally distributed if the significant number is greater than 0.05 and the data is not normally distributed if the significant number is less than 0.05 . Next is the variance homogeneity test. The data from the scores of the two samples were tested for homogeneity to determine that the two groups were relatively the same or homogeneous. The homogeneity test of variance in this study assisted by SPSS 17.0 for Windows program at a significance level of 0.05 . The test criteria using the SPSS 17.0 for Windows program in the Test of Homogeneity of Variance is that the data has a homogeneous variance if the obtained significant number is greater than 0.05 and it has a non-homogeneous variance if the significant number is less than 0.05 . Based on the data analysis, the results of the normality test between the data distribution and the variance homogeneity test in the experimental group and the control group were presented in Table 2 as follows.

Tabel 2. The Summary of Normality Test Results of Data Distribution and Variance Homogeneity

\begin{tabular}{|c|c|c|c|c|c|c|}
\hline \multirow[b]{2}{*}{ Data } & \multirow[b]{2}{*}{ Group } & \multicolumn{3}{|c|}{ Normality } & \multicolumn{2}{|c|}{ Variance Homogeneity } \\
\hline & & $\begin{array}{l}\text { Kolmogorov- } \\
\text { Smirnov }^{\mathrm{a}} \\
\text { Significant }\end{array}$ & $\begin{array}{c}\text { Shapiro-Wilk } \\
\text { Significant }\end{array}$ & Description & Significant & Description \\
\hline Matematika & Experimental & 0.155 & 0.310 & Normal & & \\
\hline $\begin{array}{l}\text { Learning } \\
\text { Outcome }\end{array}$ & Control & 0.108 & 0.177 & Normal & 0.460 & Homogeneous \\
\hline
\end{tabular}

Based on the data in the table above, it showed that the Kolmogorov-Smirnov and Shapiro-Wilk statistics had a significant number greater than 0.05. So, it can be concluded that the Mathematics learning outcomes data are normally distributed. Meanwhile, the variance homogeneity test showed that a significant number was greater than $0.05(0.460>0.05)$. Thus, it can be concluded that the Mathematics learning outcomes data in the experimental group and the control group are homogeneous.

Based on the prerequisite test of data analysis, it was found that the post-test results of the experimental group and the control group were normal and homogeneous. Therefore, it can be continued with testing the research hypothesis $\left(\mathrm{H}_{1}\right)$ and the null hypothesis $\left(\mathrm{H}_{0}\right)$. In this study, the t-test (Independent Samples Test) was applied as hypothesis testing assisted by SPSS 17.0 for Windows program at the 0.05 significance level. The results of hypothesis testing were presented in Table 3 as follows.

Table 3. The Summary of Hypothesis Test

\begin{tabular}{lccccccc}
\hline \multicolumn{1}{c}{ Data } & Group & Variance & $\mathbf{N}$ & Db & $\mathbf{t}_{\text {count }}$ & $\mathbf{t}_{\text {table }}$ & Summary \\
\hline $\begin{array}{l}\text { Matematika } \\
\text { Learning }\end{array}$ & Experimental & 2.37 & 26 & & & & 2,021 \\
Outcome & Control & 3.53 & 26 & 50 & 14,354 & $\mathrm{t}_{\text {count }}>\mathrm{t}_{\text {table }}$ \\
$\mathrm{H}_{0}$ is rejected
\end{tabular}

Based on the calculation results of the t-test above, it is obtained that the t-test was 14.354 which is then compared with the $\mathrm{t}$-table at the $5 \%$ significance level with $\mathrm{db}=\mathrm{n} 1+\mathrm{n} 2-2=26+26-2=50$ around 2.021. It showed that $t_{\text {count }}$ was greater than $t_{\text {table }}$ (tcount $>$ ttable) so that $\mathrm{H}_{0}$ was rejected and $\mathrm{H}_{1}$ was accepted. It means that there is a significant difference in Mathematics learning outcomes between students who were taught with the video media assisted the Teams Games Tournament (TGT) learning model and students who were not taught using the video media assisted the Teams Games Tournament (TGT) learning model in the fifth grade students in Cluster VI, Seririt Subdistrict, Academic Year 2019/2020. With a significant difference, it can be interpreted that there is an influence of the video media assisted the Teams Games Tournament (TGT) learning model on the Mathematics learning outcomes in the fifth grade students in Cluster VI, Seririt District, Academic Year $2019 / 2020$.

Based on the research results, it can be seen that there is a significant difference in Mathematics learning outcomes between students who are taught with the video media assisted the Teams Games Tournament (TGT) learning model and students who are not taught using the video media assisted the Teams Games Tournament 
(TGT) learning model in the fifth grade students in Cluster VI, Seririt District, Academic Year 2019/2020. Based on this significant difference, it can be seen the effect of the video media assisted the Teams Games Tournament (TGT) learning model on student mathematics learning outcomes. The influence of students' mathematics learning outcomes between the control group and the experimental group is caused by different treatment given during the learning process. In addition, the influence of students 'mathematics learning outcomes between the experimental group and the control group can also be seen from the difference in the average score on students' mathematics learning outcomes from two groups and the t-test results.

The mathematics learning process in the control group was dominated by teachers. In the control group, the teacher dominated the learning process by explaining the subject matter, providing examples, guiding problem solving, and answering questions posed by students. Students' activities were mostly sitting, listening, taking notes, and memorizing. Students tend to be passive in the learning process, easily bored, quickly sleepy, not focused on learning so students often talk with friends and joke with each other. Some students are active during learning while other students are not used to being active to ask or respond to other friends' questions. It causes the mathematics learning outcomes of students who are not taught using the Teams Games Tournament learning model assisted by video media decrease.

Unlike the Mathematics learning process in the experimental group using the Teams Games Tournament learning model assisted by video media, it allows all students to play an active role in the learning process and explore more deeply the material with group members. The use of video media assisted Teams Games Tournament learning model in the learning process contains elements of academic games (tournament) by involving the learning activities of each student member in heterogeneous groups through collaboration to earn points for the team. The implementation of the TGT learning model will have a major effect on the activeness of all students in the learning process (Agung, 2014). This model emphasizes student participation which contains elements of games and tournaments so that students do not feel bored in participating the learning activities (Rusmiati, 2019; Rofiqet et al., 2019). The syntax of the video media assisted Teams Games Tournament learning model consists of five stages. The findings in the experimental group learning can be explained as follows.

The first stage of the video media assisted the Teams Games Tournament (TGT) learning model is class presentation. At this stage, the teacher provides information or learning material using video media while students pay attention to the learning video and listen to the teacher's explanation. The presence of video media makes it easy for students to understand a concept. The advantages of video media can be used as a solution to overcome students' low ability to understand a concept (Supryadi, 2013; Alamsyah et al., 2019). Through the use of video media in providing information or learning material provided by the teacher, students are ready to receive learning, they are very enthusiastic about watching videos and understanding learning material from videos given by the teacher, and note important things from the teacher's explanation. The use of audio visual media (instructional video media) can help students understand the subject matter. The teacher has a role as a facilitator in learning when providing information or learning materials using video media. The role of the teacher as a facilitator is seen when explaining the material and giving responsibility to students to help other students understand the subject matter (Azira, 2018; Septiawan, 2017; Isti et al., 2019).

The second stage of video media assisted the Teams Games Tournament (TGT) learning model is a group. At this stage, students form heterogeneous groups guided by the teacher. All students are enthusiastic to find groups based on the teacher's direction. Students actively work together in completing assignments given by the teacher and have mutual responsibility among group members. This finding is supported by the study from (Setiawan, 2017; Mahardi, 2019) that after implementing the Teams Games Tournament learning model, students can play an active role in learning without depending on the teacher, students can be responsible, motivate each other and work together in solving problems or tasks from the teacher. Students can learn the material provided by the teacher with the group well and the goals and success of the group are not only in terms of understanding a lesson or working to solve problems but also learning something as a group. In addition, the interactions in groups can train students to accept other group members who have different backgrounds. Through group study, the ability to communicate and exchange student opinions will be well honed. In addition, learning in groups will give other students a sense of competition (Suryanata, 2017; Mayani \& Farnandes, 2019).

The third stage of video media assisted the Teams Games Tournament (TGT) learning model is games. At this stage, students listen carefully to the direction about the process and rules of the game tournament given by the teacher. The questions in the game are compiled and designed from material that is relevant to the presented material. Students really like learning by playing games. This finding is inline with (Septiawan, 2017; Rohmah, 2016) state that students like learning because there are games and tournaments. The provided games can make learning fun and students are not bored in following the Mathematics learning process. In addition, students at the elementary level still play dominant. Considering this situation, if learning adds with game, students will be more enthusiastic and students have a great willingness to participate in learning. 
The fourth stage of video media assisted the Teams Games Tournament (TGT) learning model is a tournament. Students are very enthusiastic about participating in the tournament. Students work together in groups and they are used to diligently reading books because students want to be winners in every learning activity to get points for their team. Students dare to answer questions given by the teacher. This finding is supported by the study from (Muliantika, 2017; Kii \& Dewa, 2020) states that after implementing the Teams Games Tournament (TGT) type learning model, students become diligent in reading books and looking for other sources of teaching material. During the tournament, the teacher collects scores from each group.

The fifth stage of the video media assisted the Teams Games Tournament (TGT) learning model is group awards. Each group of students is given an award by the teacher based on the obtained score. For example, the group with the highest score gets a reward while the group with low score is given motivation. Students feel appreciated for the efforts made with the group. This finding is supported by (Muliantika, 2017; Gunantara, 2018) which states that after implementing the Teams Games Tournament (TGT) type learning model, students feel appreciated for their efforts. Students become enthusiastic in learning and motivated to achieve optimal learning outcomes. Giving awards to winning groups can arouse students' enthusiasm for learning and provide motivation to each group member to maintain the success of their group in achieving maximum learning outcomes.

The group of students who were taught with the video media assisted the Teams Games Tournament (TGT) learning model obtained an average score of 18.85 Mathematics learning outcomes which were categorized as a very good category while the group of students who were not taught using the video media assisted the Teams Games Tournament (TGT) learning model obtained an average score of 18.85. The average score was 11.77 which was categorized as a sufficient category. It means that the average score of mathematics learning outcomes in the experimental group is higher than the control group. In the t-test analysis results obtained $\mathrm{t}_{\text {count }}=14.354$ and $\mathrm{t}_{\text {table }}=2.021$ with $\mathrm{db}=50$ at the $5 \%$ significance level. Based on the results of the $\mathrm{t}$ test calculation, it can be seen that $t_{\text {count }}>t_{\text {table }}$ so that $\mathrm{H}_{0}$ was rejected and $\mathrm{H}_{1}$ was accepted. It means that there is a significant difference in Mathematics learning outcomes between students who are taught with the video media assisted the Teams Games Tournament (TGT) learning model and students who are not taught using the video media assisted the Teams Games Tournament (TGT) learning model in the fifth grade students in Cluster VI, Seririt Subdistrict, Academic Year 2019/2020. With a significant difference and the average score of the experimental group's Mathematics learning outcomes is higher than the control group, it means that there is an effect of video media assisted the Teams Games Tournament (TGT) learning model on the Mathematics learning outcomes in the fifth grade students in Cluster VI, Seririt District, Academic Year 2019/2020.

Based on the findings of his study, the implementation of the video media assisted the Teams Games Tournament (TGT) learning model has a significant effect on the mathematics learning outcomes of the experimental group students. With the collaboration of models and video media, the class becomes more comfortable, students are more active, and the growth of excellent teamwork. It is because students work together in groups to complete the assigned task. This collaborative model and media make students complement each other so that they have the same knowledge.

\section{Conclusion}

The result of this study indicates that the video media assisted the Teams Games Tournament (TGT) learning model has significant effect on students' mathematics learning outcomes. This is due to differences on students' mathematics learning outcomes. The results of hypothesis testing using the $\mathrm{t}$-test also show that $\mathrm{t}_{\text {count }}=$ $14.354>\mathrm{t}_{\text {table }}=2.021$ (at the 5\% significance level) so that $\mathrm{H}_{0}$ is rejected and $\mathrm{H}_{1}$ is accepted. Thus, there is a significant difference on students' Mathematics learning outcomes between the experimental group and the control group, it can be interpreted that video media assisted the Teams Games Tournament (TGT) learning model influences on the Mathematics learning outcomes in the fifth grade students in Cluster VI, Seririt District, Academic Year 2019/2020.

\section{References}

Agung, A. A. G. 2014. Metodologi Penelitian Pendidikan. Yogyakarta: Aditya Media Publishing.

Alamsyah, R., Toenlioe, A. J., \& Husna, A. (2019). Pengembangan video pembelajaran kepenyiaran materi produksi program televisi untuk mahasiswa Teknologi Pendidikan Universitas Negeri Malang. Jurnal Kajian Teknologi Pendidikan, 1(3), 229-236.

Azira, M., Putrini, L. P., \& Japa, I. G. N. 2018. "Pengaruh Model Pembelajaran Team Games Tournament (TGT) Bermediakan Questions Box terhadap Hasil Belajar IPA". E-Journal Universitas Pendidikan Ganesha, Volume 1, Nomor 3, (hlm. 204-213). 
Bahagiani, I., Suryana, Y., \& Ganda, N. 2017. "Pengaruh Model Pembelajaran Kooperatif Tipe Teams Games Tournaments (TGT) terhadap Kemampuan Berpikir Kreatif Siswa". Jurnal Ilmiah Pendidikan Guru Sekolah Dasar, Volume 4, Nomor 1, (hlm. 196-205).

Bungsu, T. K., Vilardi, M., Akbar, P., \& Bernard, M. (2019). Pengaruh Kemandirian Belajar Terhadap Hasil Belajar Matematika Di Smkn 1 Cihampelas. Journal on Education, 1(2), 382-389.

Cahyaningsih, U. 2017. "Pengaruh Model Pembelajaran Kooperatif Tipe Team Games Tournament (TGT) terhadap Hasil Belajar Matematika Siswa SD". Jurnal Cakrawala Pendas,

Candra, N. M. Y., Putra, M., \& Ardana, I. K. 2017. "Pengaruh Model Pembelajaran Kooperatif Tipe Teams Games Tournament Berbantuan Peta Konsep terhadap Kompetensi Pengetahuan IPA Siswa Kelas IV SD Gugus Letda Made Putra". E-Journal MIMBAR PGSD, Volume 5, Nomor 2, (hlm. 1-10).

Damayanti, S. \& Apriyanto, M. T. 2017. "Pengaruh Model Pembelajaran Kooperatif Tipe TGT (Teams Games Tournament) terhadap Hasil Belajar Matematika". Jurnal Kajian Pendidikan Matematika, Volume 2, Nomor 2, (hlm. 235-244).

Dantes, N. 2017. Desain Eksperimen dan Analisis Data. Depok: PT Raja Grafindo Persada.

Dewi, N. W. S. K., Parmiti, D. P., \& Japa, I. G. N. 2019. "Pengaruh Model Pembelajaran Probing Prompting Berbantuan Media Video terhadap Hasil Belajar IPA". Indonesian Journal of Educational Research and Review,

Effendi, L. A. 2012. "Pembelajaran Matematika dengan Metode Penemuan Terbimbing untuk Meningkatkan Kemampuan Representasi dan Pemecahan Masalah Matematis Siswa SMP". Jurnal Penelitian Pendidikan, Volume 13, Nomor 2, (hlm. 1-10). Tersedia pada http://jurnal.upi.edu/file/LeoAdhar.pdf (diakses tanggal 19 Desember 2019).

Egok, A. S. (2017). Kemampuan berpikir kritis dan kemandirian belajar dengan hasil belajar matematika. Jurnal Pendidikan Dasar UNJ, 7(2), 186-199.

Gunarta, I. G. 2018. "Pengaruh Model Pembelajaran TGT Berbantuan Media Question Card terhadap Hasil Belajar IPA". Jurnal Pedagogi Dan Pembelajaran, Volume 1, Nomor 2, (hlm. 112-120).

Hakim, S. A. \& Syofyan, H. 2017. "Pengaruh Model Pembelajaran Kooperatif Tipe Teams Games Tournament (TGT) terhadap Motivasi Belajar IPA di Kelas IV SDN Kelapa Dua 06 Pagi Jakarta Barat". International Journal of Elementary Education,

Hermayanti, P., Sumantri, M., \& Sudarma, I. K. 2017. "Pengaruh Model Pembelajaran Kooperatif Tipe Team Games Tournament Berbantuan Peta Konsep terhadap Hasil Belajar IPA". Jurnal Ilmiah Sekolah Dasar,

Ismah, Z., \& Ernawati, T. (2018). Pengaruh Model Pembelajaran Kooperatif Tipe Teams Games Tournament (TGT) Terhadap Hasil Belajar Ipa Siswa Kelas VIII SMP Ditinjau Dari Kerjasama Siswa. Jurnal Pijar Mipa, 13(1), 82-85.

Isti, L. A., Agustiningsih, A., \& Wardoyo, A. A. (2020). Pengembangan Media Video Animasi Materi Sifat-Sifat Cahaya Untuk Siswa Kelas IV Sekolah Dasar. EduStream: Jurnal Pendidikan Dasar, 4(1), 21-28.

Kii, O. A., \& Dewa, E. (2020). Simulasi Phet Sebagai Media Pembelajaran Berbasis Komputer Pada Model Pembelajaran Team Games Tournament Untuk Meningkatkan Aktivitas Dan Hasil Belajar Fisika Mahasiswa. Jurnal Riset Teknologi dan Inovasi Pendidikan (JARTIKA), 3(2), 360-367.

Komalasari, K. 2010. Pembelajaran Kontekstual: Konsep dan Aplikasi. Bandung: PT Refika Aditama.

Listyarini, D. W. \& Asari, A. R. F. 2018. "Pengaruh Model Teams Games Tournament Berbantuan Permainan Halma terhadap Minat dan Hasil Belajar pada Materi Bunyi Siswa Kelas IV Sekolah Dasar". Jurnal Pendidikan: Teori, Penelitian, dan Pengembangan, Volume 3, Nomor 5, (hlm. 538-543).

Mahardi, I P. Y. S., Murda, I N., \& Astawan, I. G. 2019. "Model Pembelajaran Teams Games Tournament Berbasis Kearifan Lokal Trikaya Parisudha terhadap Pendidikan Karakter Gotong Royong dan Hasil Belajar IPA". Jurnal Pendidikan Multikultural Indonesia, Volume 1, Nomor 1, (hlm. 98-107).

Maulidina, Z., Nuriman, \& Hutama, F. S. 2018. "Pengaruh Model Pembelajaran Kooperatif Tipe TGT Berbantuan Media TTS terhadap Hasil Belajar Siswa". Jurnal Pendidikan Sekolah Dasar, Volume 4, Nomor 2, (hlm. 140-147).

Mayani, D. S., \& Fernandes, R. (2019). Penerapan Model TGT dengan Variasi LKPD Berbasis Kontekstual 
Untuk Meningkatkan Minat Belajar Sosiologi Siswa Kelas XI IPS 1 SMAN 1 2x11 Enam Lingkung Padang Pariaman. Jurnal Sikola: Jurnal Kajian Pendidikan dan Pembelajaran,

Muliantika, P. F., Margunayasa, I G., \& Wibawa, I. M. C. 2017. "Pengaruh Model Pembelajaran Tipe Teams Games Tournament (TGT) terhadap Hasil Belajar IPA Siswa Kelas V SD". E-Journal MIMBAR PGSD, Volume 5, Nomor 2, (hlm. 1-10).

Novianingsih, H. (2016). Pendekatan Pembelajaran Aktif, Kreatif, Efektif, dan Menyenangkan dalam Pembelajaran Matematika Sekolah Dasar. Jurnal Pendidikan Guru Sekolah Dasar, 1(1), 1-11.

Oktarianingsih, N. L., Abadi, IB G. S., \& Putra, D. K. N. S. 2019. "Pengaruh Model Pembelajaran Teams Games Tournament Berbantuan Media Visual terhadap Kompetensi Pengetahuan IPA". Jurnal Penelitian Dan Pengembangan, Volume 3, Nomor 3, (hlm. 208-215).

Pangestu, P., \& Santi, A. U. P. (2016). Pengaruh pendidikan matematika realistik terhadap suasana pembelajaran yang menyenangkan pada pelajaran matematika sekolah dasar. FIBONACCI: Jurnal Pendidikan Matematika dan Matematika, 2(2), 58-71.

Rahmawati, N. K. (2017). Implementasi Teams Games Tournaments dan Number Head Together ditinjau dari Kemampuan Penalaran Matematis. Al-Jabar: Jurnal Pendidikan Matematika, 8(2), 121-134.

Rofiq, M. A., Mahmud, M. E., \& Musfiroh, I. A. (2019). Peningkatan Hasil Belajar Fiqih Melalui Model Kooperatif Tipe Teams Games Tournament (TGT) Kelas V MI At Tarbiyah Loa Janan. Tarbiyah Wa Ta'lim: Jurnal Penelitian Pendidikan dan Pembelajaran, 6(2), 109-129.

Rohmah, E. A. W. 2016. "Pengaruh Model Pembelajaran Kooperatif Tipe Teams Games Tournament (TGT) Berbantuan Media Game Online terhadap Pemahaman Konsep dan Penalaran Matematis Siswa". Jurnal Pendidikan Dasar, Volume 8, Nomor 2, (hlm. 126-143).

Rusmiati, R. \& Nugroho, A. S. 2019. "Pengaruh Model Pembelajaran TGT dengan Media Pop Up Terhadap Hasil Belajar Kelas IV Tema 6 Cita-Citaku Subtema 3". Jurnal Pedagogi Dan Pembelajaran, Volume 2, Nomor 2, (hlm. 241-248).

Saptayanti, G. A. K. E., Wibawa, I M. C., \& Pudjawan, K. 2016. "Pengaruh Model Pembelajaran Kooperatif Tipe TGT (Teams Games Tournament) terhadap Hasil Belajar Matematika". E-Journal MIMBAR PGSD, Volume 4 Nomor 1, (hlm. 1-11).

Septiawan, I M. A. E., Rati, N. W., \& Murda, I. N. 2017. "Pengaruh Model Pembelajaran Kooperatif Tipe TGT Berbantuan Media Audio Visual terhadap Hasil Belajar IPA". E-Journal MIMBAR PGSD, Volume 5, Nomor 2, (hlm. 1-11)

Setiawan, W. D. 2017. "Pengaruh Penggunaan Model Pembelajaran Kooperatif Tipe Teams Games Tournament dan Model Pembelajaran Ekspositori terhadap Hasil Belajar Pendidikan Kewarganegaraan". Jurnal Pendidikan Ke-SD-An, Volume 4, Nomor 1, (hlm. 216-219).

Solihah, A. 2016. "Pengaruh Model Pembelajaran Teams Games Tournament (TGT) terhadap Hasil Belajar Matematika". Jurnal Susunan Artikel Pendidikan, Volume 1, Nomor 1, (hlm. 45-53).

Sugiyono. 2011. Metode Penelitian Kuantitatif Kualitatif dan $R \&$ D. Bandung: Alfabeta.

Sumewati, N. L. S., Tastra, I D. K., \& Murda, I. N. 2018. "Pengaruh Model Pembelajaran Kooperatif Tipe Teams Games Tournament Berbantuan Media Lingkungan terhadap Hasil Belajar IPA Siswa Kelas IV SD Gugus V Kecamatan Sawan". E-Journal MIMBAR PGSD,

Supryadi, P. E., Jampel, I N., \& Riastini, P. N. 2013. "Penerapan Media Video Pembelajaran sebagai Aplikasi Pendekatan Contekstual Teaching Learning untuk Meningkatkan Hasil Belajar IPA Siswa Kelas V". EJournal MIMBAR PGSD, Volume 1, Nomor 1, (hlm. 1-10

Suryanata, I K. A., Suartama, I K., \& Putri, D. A. W. M. 2017. "Pengaruh Model Pembelajaran Kooperatif Tipe Teams Games Tournament (TGT) Berbantuan Mind Mapping terhadap Hasil Belajar IPA Kelas V SD". E-Journal MIMBAR PGSD, Volume 5, Nomor 2, (hlm. 1-10).

Susanto, A. 2013. Teori Belajar \& Pembelajaran di Sekolah Dasar. Jakarta: Kencana Prenada Media Group.

Syahrir, S., \& Kusnadin, K. (2013). Pengembangan Model Pembelajaran Matematika Sekolah Dasar yang Menyenangkan dan Menantang. Media Pendidikan Matematika, 1(2), 145-157.

Tara, O. S., \& Karyanti, K. (2019). Upaya Meningkatkan Hasil Belajar Matematika dengan Menggunakan 
Model Pembelajaran TGT Berbantuan dengan Media Tali Pas pada Peserta Didik Di SDN 2 Petuk Bukit Tahun Pelajaran 2017/2018. Tunas: Jurnal Pendidikan Guru Sekolah Dasar, 4(2), 26-34.

Trianto. 2009. Mendesain Model Pembelajaran Inovatif-Progresif. Jakarta: Kencana Prenada Media Group.

Wajo, E., \& Kartika, E. D. (2020). Pengaruh Model Pembelajaran Tipe Artikulasi dan Team Games Tournament Terhadap Kemampuan Representasi Matematis. Laplace: Jurnal Pendidikan Matematika, 3(1), 1-7. 